\title{
Securities Class ACtions, Corporate GovernanCe and Managerial Agency Problems*
}

\author{
Philip E. Strahan \\ Federal Reserve Bank of New York \\ (212) 720-1617 \\ philip.strahan@ny.frb.org
}

July 1998

\begin{abstract}
This paper provides support for the proposition that securities class actions help solve agency problems. Two key findings support this conclusion. First, firms that are more likely to suffer from agency problems are more likely to face class actions. Risky firms, large firms, young firms, low market-to-book firms and non-dividend paying firms as of the end of 1990 were more likely to face a class action filing during the January 1991 to March 1998 period. Second, the probability of CEO turnover increases dramatically after class action filings. The increase can not be explained by omitted firm-specific characteristics, financial distress, or the possibility that CEO turnover increases the likelihood that a lawyer will file a class action.
\end{abstract}

JEL Classification Code: G3

*I thank Frederick Dunbar and Todd Foster of National Economic Research Associates, Inc. (NERA) for providing me with much of the data used in this study, and also for providing comments and suggestions. I also thank Sandra Black, Don Morgan, Marc Saidenberg, Catherine Strahan and seminar participants at the Federal Reserve Bank of New York and NERA for helpful comments Oba McMillan, Colleen Sellers and Eliza Wright for research assistance. The opinions expressed here are the author's and do not necessarily reflect the opinions of the Federal Reserve Bank of New York or the Federal Reserve System. 


\section{Securities Class Actions, Corporate Governance and Managerial Agency Problems}

\section{Introduction}

Why does the United States have the largest and most liquid capital market in the world? Why is ownership structure of U.S. corporations so diffuse? In Italy, more than three-quarters of manufacturing companies are controlled by a single shareholder or family (Pagano and Röell, 1998). In contrast, only about 20 percent of the shares of publicly-traded manufacturing companies are held by insiders in the U.S. (Holderness, Kroszner and Sheehan, 1997). More pointedly, why are small investors willing to hand over so much of their wealth to managers of U.S. corporations? As Shleifer and Vishny put it, "it is not entirely obvious why the suppliers of capital get anything back. After all, they part with their money, and have little to contribute to the enterprise afterward (Shleifer and Vishny, 1997)."

In the past, analysts have argued that capital markets in the U.S. became dominant both because of strict oversight and disclosure standards stemming from creation of the Securities and Exchange Commission (SEC), and because of limits placed on the role of financial intermediaries during the 1930s (Prowse, 1996). Shleifer and Vishny (1997) also emphasize the ability of small investors in the U.S. to sue corporate officers and directors for securities law violations. These lawsuits are potentially quite powerful because entrepreneurial lawyers can organize small investors into a class and sue on behalf of that class. Since one-third of damages typically go to the lawyers, their incentives to collect information and act on that information are much greater than a small shareholder's incentive, since the benefits of any costly actions taken would be shared with all other shareholders (Martin, Juneja, Foster and Dunbar, 1996). 
This paper assesses whether class actions help mitigate owner/manager agency conflicts and, by extension, play a role in explaining the success of capital markets in the United States. An alternative view is that securities class actions represent nothing more than rent-seeking behavior by opportunistic lawyers. Such arguments were made surrounding passage of the Private Securities Litigation Reform Act of 1995 (the "Reform Act"). The Reform Act made it more difficult for plaintiffs to file securities fraud cases and created a "safe harbor" to encourage the release of forward-looking information such as earning projections (Grundfest and Perino, 1997). Advocates of reform argued that lawyers were taking advantage of unlucky companies whose stock prices experienced unusually large declines. According to this view, plaintiffs' lawyers would file a complaint that management failed to disclose information to the market in a timely manner following a stock price drop, and they would then extract a settlement from the company's Directors' and Officers' (D\&O) insurance policy.

If securities class actions really are important in solving corporate governance problems, then we ought to observe the following: (1) Firms with greater ex ante agencies problems are more likely to be sued. (2) Either salutary changes in corporate governance mechanisms occur after class actions, or management turns over following the class actions. (If existing corporate governance mechanisms are functioning properly, then we may only observe management turnover.)

In the first set of empirical tests, I find that large firms, low market-to-book firms, firms with more intangible assets, high-risk firms, and young firms are all more likely to face class actions. Each of these results is consistent with the idea that agency problems increase the risk of facing a class action. Previous studies have shown that stock price volatility, trading volume, and 
market capitalization are higher at companies facing class actions (Jones and Weingram 1996) and that these companies appear to disclose unusually optimistic earnings projections (Beck and Bhagat 1997), but this is the first study that I know of that relates measures of agency problems to the prevalence of class actions. Some of the findings, such as the effect of risk on the likelihood of facing a class action, are also consistent with the legal rent-seeking hypothesis. These two hypotheses are not mutually exclusive, and both make similar predictions for some variables. Nevertheless, many of the variables related to agency problems, such as firm age, tangible assets and the market-to-book ratio, would not affect the likelihood of being sued under the legal rent-seeking hypothesis.

I also test whether variables that may themselves be chosen to mitigate agency problems -ownership structure, capital structure, and dividend policy -- are related to class actions. While Alexander and Cohen (1997) find that the incidence of corporate criminal fraud declines when insider holdings rise from 0 to 10 percent, I find that managerial shareholdings are not linked to the likelihood of facing a securities class action. This result is consistent with optimal ownership structure that, in equilibrium, is uncorrelated with residual agency problems. Firms that consistently fail to pay dividends, however, are about 60 percent more likely to face a class action than dividend payers. Following La Porta, Lopez, Shleifer and Vishny (1998), I argue that dividend policy acts as a proxy for residual agency problems: firms where outside investors can induce managers to pay out cash have less severe agency problems than firms that never pay dividends. As a result, the non-payers are more likely to face class actions.

In the second set of tests, I consider whether class actions lead to changes in corporate governance structures. While ownership structure and board composition do not change after 
securities class actions, the likelihood of CEO turnover nearly doubles, and the increase is statistically significant. Moreover, the increase in the probability of turnover is larger following lawsuits that have more merit, where merit is defined by the size of the settlement relative to a measure of investor losses typically used by plaintiffs in settlement negotiations; there is no statistically significant increase in the probability of CEO turnover following lawsuits that have below-average merit.

This last result is important given the mixed results in the literature on the effect of corporate fraud and securities fraud on management turnover. Aggrawal, Jaffe and Karpoff (1998) find no increase in the likelihood of CEO turnover after the revelation of fraud, once firmspecific characteristics are taken into account. Romano (1991) finds that top management turns over more frequently at firms that faced securities litigation both before and after the lawsuits. ${ }^{1}$ Niehaus and Roth (1998) find that firms involved in securities class actions are more likely to experience turnover than a matched sample of firms not facing class actions. In this paper, I use a panel dataset to assess the impact of securities class actions on the likelihood of CEO turnover, rather than comparing sued companies with companies that were not sued. The advantage of the panel technique is that the results are based on changes in a given firm's probability of experiencing turnover across time. As such, omission of firm-specific characteristics that may be related to both the incidence of turnover and the incidence of experiencing a class action (or, in the Aggrawal et al paper, fraud), is much less of a problem.

\section{Background: how securities class actions work}

\footnotetext{
${ }^{1}$ Romano focuses on derivative actions rather than securities class actions, as in this paper.
} 
Small investors face two problems in dealing with entrepreneurs. First, asymmetric information leads to an adverse selection effect: insiders have an incentive to sell overvalued stock to outsiders and buy undervalued stock from them. Second, free rider problems severely reduce the incentive for dispersed outsiders to monitor managers. The first problem is addressed in the U.S. by prohibition on insider trading and the duty for managers to disclose information to shareholders. Much of the enforcement of these laws occurs through private litigation, rather than direct actions by the SEC (Dunbar and Juneja, 1994). The free-rider problem is addressed in part by the ability of lawyers to organize a class and litigate (that is, collect costly information and act on that information) for that class. ${ }^{2}$ Lawyers typically receive one-third of the settlement, thereby concentrating their incentives and helping solve the free-rider problem (Martin, Juneja, Foster and Dunbar, 1996).

${ }^{2}$ Free-rider problems are partly solved by concentrated ownership and ownership by blockholders. However, as pointed out by Gorton and Kahl (1997), concentrated ownership requires wealthy investors, which is a scarce resource. They present a model in which institutional investors provide a second means through which ownership can be concentrated and thereby help solve free-rider problems. 
Securities class action lawsuits stem from managers' duty to disclose information regarding the value of securities to their owners under the Securities Act of 1933 and the Securities and Exchange Act of $1934 .^{3}$ By providing outside investors with accurate information, the intent of these laws is to reduce asymmetries of information between outside investors and insiders and thereby enhance outsiders' willingness to provide capital to insiders. Securities class actions typically occur when a lawyer specializing in such litigation, after observing a large decline in a firm's stock price in response to some adverse news, files a complaint on behalf of all investors who purchased the stock before the price declined but after the period when management was legally bound to disclose the material information.

The best way to explain these cases is with an example. ${ }^{4}$ On November 3, 1997, plaintiffs' lawyers filed a complaint against the SoftCo Corporation and some of its senior officers alleging violations of the Securities and Exchange Act of 1934 and the SEC's rule 10b-5. The complaint was filed on behalf of all open market purchasers of SoftCo's common stock between March 12, 1997 and October 8, 1997. Plaintiffs argued that the company made false statements regarding their purchase of American ChipCo that artificially inflated the market price of the common stock between these two dates (the "class period"). Therefore, plaintiffs alleged that purchasers during the class period suffered damages equal to the difference between the actual share price and the price that would have prevailed had managers accurately disclosed the adverse consequences associated with the purchase of American ChipCo. Plaintiffs argued further that insiders profited

\footnotetext{
${ }^{3}$ In contrast, derivative class actions allow current shareholders to sue management on behalf of the company based on the argument that the firm has been mismanaged (Dunbar and Juneja, 1994).

${ }^{4}$ This example is based on a real complaint. Names and dates have been changed to conceal the identity of the defendant.
} 
from the price inflation by selling large percentages of their holdings of SoftCo during the class period.

As in the example, plaintiffs' lawyers often allege that managers are intentionally withholding information in order to trade profitably with ill-informed outsiders, particularly following passage of the Reform Act (Grundfest and Perino, 1997). If plaintiffs are to be believed, then these instances are clear-cut manifestations of agency problems associated with a separation of ownership and control (Berle and Means 1935, Jensen and Meckling 1976). Critics of securities class actions argue, however, that much of what occurs can be described more accurately as rent-seeking behavior by lawyers. For instance, Alexander (1991) argues that settlements occur regardless of the merits of cases, and, crucially, that the settlement amounts are not related to the merits. Therefore, lawyers have a powerful incentive to sue any unlucky company whose stock has recently experienced a sharp drop. I will call this the 'legal rentseeking' hypothesis.

On the other hand, using a set of Canadian firms, Core (1997) shows that the premiums charged for D\&O insurance reflect the strength of corporate governance. This suggests that firms with greater agency problems (weak corporate governance structures) impose greater potential liability on insurance companies and pay for it. This gives firms an incentive to correct their governance problems. Moreover, Niehaus and Roth (1998) show that although insider selling does not seem to occur more frequently during the class period, sued companies are more likely to issue new shares during the class period. On balance, then, there appears to be no consensus about whether these lawsuits have economic value. In the next two sections, I show that they do.

\section{Ex ante measures of agency problems predict class actions}


If securities class actions help solve manager/owner agency problems, then firms with greater agency problems should be more likely to be sued. On the other hand, if securities class actions occur because of legal rent-seeking, then the incidence of these lawsuits should only reflect lawyers' incentive to file claims. These two hypotheses are not mutually exclusive, and both make similar predictions for some variables. Nevertheless, many of the variables related to agency problems would not affect the likelihood of being sued under the legal rent-seeking hypothesis.

\section{Sample and model specification}

A list of all companies that had a securities class action lawsuits filed against them in either federal or state court between January 1991 and March 1998 was generously provided to me by National Economic Research Associates, Inc (NERA). ${ }^{5}$ These filings were compiled from the Securities Class Action Alert. I then match the sued companies to the 1990 Standard \& Poor's Compustat for financial characteristics and to the Center for Research in Securities Prices (CRSP) for stock price information. Of the 1,600 companies that were sued over the period, 751 of these appear on Compustat in 1990; 636 of these were sued once during the period, 90 were sued twice, 21 were sued three times, and 4 were sued more than three times. The unconditional probability of facing at least one lawsuit over the period for the Compustat sample was about 0.1

\footnotetext{
${ }^{5}$ It is important to consider filings in both state and federal court because the percentage of cases filed in state court increased sharply after passage of the Reform Act (Grundfest and Perino, 1997). Note that I have also estimated the model using filings before passage of the Reform Act. These results are very similar and are available on request.
} 
(751 firms sued divided by 7,584 firms on the 1990 Compustat). ${ }^{6}$

${ }^{6}$ Damages associated with newly issued securities are filed under Section 11 of the 1933 Securities Act. Those involving IPOs will not appear in the analysis, since ex ante firm characteristics will not be available. Also, very small companies will not be included since they are less likely to appear in Compustat. 
To analyze how firm characteristics affect the likelihood of facing a securities class action, I estimate an ordered probit model, where the dependent variable equals the number of times that a given firm was sued. Since the explanatory variables are measured as of the end of 1990, and the set of class action filings begin in January of 1991, there is no obvious endogeneity problem that could occur if these variables were measured after the class actions were filed. ${ }^{7}$ (The results from an ordered logit model are very similar to the ones reported below.)

\section{Hypotheses and Variable Definitions}

Two sets of variables appear in the ordered probit analysis. The first set are firm-specific characteristics that are not themselves likely to be chosen by the firm in response to agency problems. These include size, market-to-book equity, tangible assets-to-total assets, stock return volatility, trading volume, age, and industry indicators. The second set, however, are potentially determined by the firm, at least in part, to help solve owner/manager agency problems, making it more difficult to predict how they should be related to the probability of securities class actions. These include leverage, dividends, and insider holdings. The results are reported with and without these variables.

\footnotetext{
${ }^{7}$ I have also estimated a hazard model in which the dependent variable is the first time a given firm is sued. In this model, firms that are sued earlier are assumed to have characteristics that increase the likelihood (hazard) of facing a suit, but all firms are assumed to be 'at risk' of a lawsuit. I used the Cox proportional hazard model, which imposes no structure on the baseline hazard rate. Thus, the hazard rate can increase or decrease non-parametrically through time. This is a useful property for these purposes because the Reform Act, passed in 1995, may have reduced the baseline hazard rate for all firms. The model assumes, however, that the Reform Act does not affect the coefficients in the hazard model. These results are similar to the ordered probit results and are available on request.
} 


\section{$\underline{\text { Firm characteristics }}$}

Table 1 presents the predicted sign on each variable under the two hypotheses (agency vs rent-seeking). Both the agency and the rent-seeking hypotheses predict that larger firms are more likely to face class actions. Residual agency problems will plague large firms more than small because the mechanisms that help solve these problems, including pay-for-performance contracts, concentration of ownership, and, perhaps most important, the market for corporate control, all work better for small firms. ${ }^{8}$ The legal rent-seeking hypothesis, however, makes the same prediction because large firms have "deep pockets." Size is measured as the log of the market capitalization of the firm's equity as of the end of 1990. Stock price and shares outstanding data are from CRSP.

The market-to-book equity ratio is included to capture managerial quality (Morck, Shleifer and Vishny, 1988). High market-to-book firms are those that are well managed and thus should be less likely to be sued (according to the agency hypothesis). The market-to-book ratio, however, has some very large outliers that skew the results. I therefore report one specification where the variable is trimmed at the 90th percentile of its distribution, and another with an indicator equal to one for firms with market-to-book ratios above the median for their industry, as defined by the two-digit SIC code. (This latter specification includes all of the observations.) The rent-seeking hypothesis predicts no relationship between market-to-book equity and the likelihood of being sued.

${ }^{8}$ Jensen and Murphy (1993) find that CEO pay is more than four times as sensitive to performance at small firms as it is at large firms. Demsetz and Lehn (1985) find that ownership is more concentrated at small firms. Morck, Shleifer and Vishny (1989) show that the incidence of being the target of a hostile takeover is a decreasing function of firm size. 
Firms with more intangible assets are likely to have greater agency problems because tangible assets are easier for outsiders to observe and value. Himmelberg and Morgan (1995) argue that tangible assets reduce firm opaqueness and thereby increase a firm's access to external capital. As evidence, they show that firms with higher levels of fixed capital are more likely to have a bond rating. According to the agency hypothesis, firms with fewer tangible assets should therefore face a higher risk of facing a class action. I use the ratio of property, plant and equipment $(\mathrm{PP} \& \mathrm{E})$ to total assets as a measure of tangibility of assets. The rent-seeking hypothesis predicts no relationship between tangible assets and the likelihood of being sued.

Riskier companies are also more likely to face class actions under the agency hypothesis. Demsetz and Lehn (1985) argue that "in less predictable environments...managerial behavior simultaneously figures more prominently in a firm's fortunes and becomes more difficult to monitor." Consistent with optimal ownership structure, they find that ownership is more concentrated at riskier firm. Holdnerness, Kroszner and Sheehan (1998) have a similar findings for managerial ownership in both 1995 and 1935. Unfortunately, the rent-seeking hypothesis makes the same prediction: the chance of a firm experiencing a large enough decline in their stock to warrant a lawyer's time to investigate whether securities laws have been violated will increase with the volatility of the stock price. I use the standard deviation of monthly returns during the 60 months between January 1986 and December 1990 as a measure of risk. ${ }^{9}$

Following Jones and Weingram (1996), I include the average rate of turnover of the firm's stock (average monthly trading volume divided by share outstanding), since the expected

\footnotetext{
${ }^{9}$ This variable requires that the firm have traded stock for the 1986 to 1990 period. I have also estimated the model without this variable (and the dividend variable, described below) so that all observations in the 1990 Compustat could be included. The results for the variables included in both specifications are similar for both models.
} 
settlement amounts increase as trading volume increases. ${ }^{10}$ If lawyers seek rents, their incentive to file a class action against a firm with actively traded shares is greater than their incentive to file against a firm whose stock trades less frequently. Trading volume and shares outstanding data are from CRSP.

${ }^{10}$ Jones and Weingram (1998) map the trading volume variable into a measure of the amount of damages typically asked for by plaintiffs based on the proportional decay model in which each share is assumed to have an equal probability of trading on each day. This transformation of the trading volume variable has a similar effect in the ordered probit models to the results presented below. 
The agency hypothesis predicts that younger companies will face more class actions, where age is defined as the number of years since the firm's stock began to trade on the exchanges. ${ }^{11}$ Firms may become more transparent as they age, reducing information asymmetries between managers and outside shareholders and thereby reducing agency problems. On the other hand, selection effects may cull out firms that suffer from severe agency problems. Either way, aging should reduce the likelihood of a firm facing a securities class action. This variable comes from CRSP.

I include a variety of industry indicator variables to control for other unexplained differences across industries. Some specifications (not reported below) include a set of indicator variables based on 1-digit SIC code. In the ones reported below, I include just three industry indicators: one for banking firms (SIC code 60); a second for regulated firms (SIC 40 [railroads], 48 [telecommunications], 49 [utilities] and 60 [banks]); and a third for firms in high-technology (SIC 357 [computer and office equipment], 737 [computer programming services]). Martin et al. (1996) show that high-technology companies and banks are (unconditionally) more likely to face securities class actions. I also include the regulated firm indicator to test the agency hypothesis. ${ }^{12}$ (Since the coefficients on the other variables are not affected by the set of industry indicators that

${ }^{11}$ Note that all of the companies in the model are at least five years old, since I use data from 1986 to 1990 to compute the stock return volatility. If anything, this selection criterion creates a bias against finding an aging effect, particularly since many securities class actions involve claims against newly issued securities such as IPOs.

12 Demsetz and Lehn (1985) argue that regulated firms face less severe agency problems, and they show that ownership is less concentrated at these firms. 
are included in the model, I only report the results with the banking, high-technology and regulated-firm indicators.)

\section{$\underline{\text { Variables potentially used to solve agency problems }}$}

Corporate governance mechanisms and capital structure may be determined, in whole or in part, to help solve managerial agency problems. This makes it difficult to predict how these variables ought to be related to the frequency of class actions under the agency hypothesis. For example, there may be no relationship between levels of insider holdings, leverage and dividend policy in equilibrium and residual agency problems, and it is residual agency problems that may be correlated with the likelihood of facing a securities class action. In contrast, the rent-seeking hypothesis predicts no relationship between these variables and the likelihood of class actions. Morck, Shleifer and Vishny (1988) argue that managerial shareholdings help align the incentives of insiders and outsiders. To test this notion, I include the fraction of shares outstanding held by officers and directors. Included in the holdings of insiders are all family shares owned by insiders as well as all outstanding options to purchase shares. Data on ownership structure are constructed from the 1990 proxy statement as made available by Disclosure, Inc. through Compact Disclosure. ${ }^{13}$ I introduce insider holdings linearly in one specification. Since Morck, Shleifer and Vishny (1988) find that managerial entrenchment dominates alignment when insider holdings range between 5 and 25 percent, I also estimate the

${ }^{13}$ One complication arises because active trading by informed insiders will affect the level of insider holdings Jordan (1998). Thus, if managers of sued companies either systematically sell shares before a lawsuit or issue new share then there will be a negative correlation between insider holdings and the likelihood of being sued. (For evidence that firms issue new equity during the class period, see Niehaus and Roth, 1998). I therefore have also used insider holdings as of 1988, three years before the first filing, to insure that managerial trading does not drive the results. These results are similar to those reported below. 
model with a linear spline with breakpoints at 5 and 25 percent.

Jensen (1986) argues that "free cash" increases opportunities for managerial misbehavior. Debt, by forcing managers to pay out free cash as interest, can help mitigate owner/manager agency problems. To test this hypothesis, I include leverage, measured as the ratio of total debt to total assets. ${ }^{14}$

\footnotetext{
${ }^{14}$ I have also included the ratio of cash to total assets, but this variable was not statistically significant.
} 
Finally, the model includes a dividend indicator equal to 1 if the firm paid a cash dividend on common equity at least once during the 5 year period between 1986 and 1990 . This variable distinguishes firms that never pay dividends over a relatively long period from those that do. Firms may fail to pay dividends because they have strong investment opportunities that they are retaining earnings to fund, and retained earnings constitute the cheapest form of financing. ${ }^{15}$ Alternatively, firms that do not pay dividends may be those firms with the most severe agency problems -- these may be firms where it is difficult for shareholders to force managers to give back profits on a regular basis. ${ }^{16}$ Information on dividend payout history comes from Compustat. Results

Table 2 compares the summary statistics for the companies that faced one or more securities class actions with those that did not. Sued firms are much larger than average: their market capitalization is about five times as large as other firms (based on the median). Given this dramatic size difference, it is not surprising that sued firms have a lower level of insider holdings, and higher trading volume. It is surprising that they seem to be about as likely to pay dividends (since large firms are much more likely to pay than small ones), are younger, and have slightly

\footnotetext{
${ }^{15}$ For evidence that internally generated funds are the cheapest source of funds, see Fazzari, Hubbard and Petersen (1988). For an alternative point of view, see Kaplan and Zingales (1997).

${ }^{16}$ I also tried the current dividend payout rate (cash dividends divided by earnings), and an indicator equal to 1 for firms that paid dividends in every year from 1986 to 1990 . Neither of these variables is significant when included with the dividend indicator described in the text, while this variable remains statistically significant when the others are included.
} 
more volatile stock prices. Table 3 reports the results from the ordered probits.

\section{Firm characteristics}

The coefficients on size, market-to-book equity, tangible assets to total assets, stock return volatility, and age are all consistent with the agency hypothesis: large firms, low market-tobook firms, firms with more intangible assets, risky firms, and young firms are more likely to face securities class actions. These effects are economically significant as well. Using a simple probit (where the dependent variable equals 1 if the firm faced one or more lawsuits), I estimate that a one standard deviation increase in the log of market capitalization (from the mean in the sample) is associated with an increase in the probability of facing a lawsuit of about 9 percentage points. This is a very large increase, given that the unconditional probability is only 10 percent. A one standard deviation increase in stock return volatility is associated with an increase in the probability of being sued of 3 percentage points, and a one standard deviation increase in the tangible assets variable is associated with a decrease in the probability of being sued of 2 percentage points. The coefficient on the market-to-book indicator suggests that highly valued companies relative to their peers in the industry are about 2 percentage points less likely to be sued than companies with low market valuations.

Both the size and volatility results are also consistent with legal rent-seeking. In addition, firms with more actively traded stock prices are more likely to be sued, again consistent with the class actions representing, at least in part, legal rent-seeking. This effect is also economically important -- a standard deviation increase in trading turnover is associated with an increased probability of being sued of about 2 percentage points.

Variables potentially used to solve agency problems 
Both leverage and dividend policy are significantly related to the likelihood of facing a class action (Table 3, columns 3 and 4). Firms with higher leverage are more likely to be sued. On its face, this result appears inconsistent with Jensen's free cash flow hypothesis, but if leverage is determined in part to solve agency problems, there is no reason to expect leverage to be correlated with residual agency problems in equilibrium. The positive relationship between leverage and the risk of facing a class action may reflect risk, since equity volatility is greater at more highly leveraged firms. Leverage may help predict future stock return volatility, even when past volatility is included in the regression.

Far more powerful is the impact of dividend policy: Firms that do not pay dividends over extended periods of time are much more likely to be sued. In fact, the probability of class actions is about 6 percentage points higher for the non-dividend payers, compared to firms that paid a dividend at least once during the $1986-90$ period. The effect of the dividend policy indicator is the only one that rivals the effect of firm size in importance. This results suggests that dividend policy can act as a powerful proxy for the degree to which a firm has solved (or failed to solve) its manager/owner agency problem. Firms that pay dividends -- that is, firms where outside investors can (somehow) induce managers to pay out cash -- have less severe agency problems than firms that consistently fail to pay dividends. As a result, the non-payers are more likely to face class 
actions. $^{17}$

Insider holdings are not related to the likelihood of class actions in either the linear model or the linear spline. As noted above, this is consistent with firm's choosing their ownership structure optimally, leading to no correlation in equilibrium between the level of insider holdings and the amount of residual agency problems. I also found no relationship between board composition, large blockholdings or institutional holdings and the presence of a class action (not shown). Since these variables have to be hand collected, I could not include them in the ordered probit analysis. Instead, I created a size- and industry-matched control group of firms that did not face a securities class action and found no statistically significant difference in board size, board insiders, large blockholdings or institutional holdings between the control group firms and the firms that faced a securities class action.

\section{Class actions lead to CEO turnover}

\footnotetext{
17 This interpretation of the dividend result is consistent with La Porta et al (1998), who find that "firms appear to pay cash out to investors because the opportunities to steal or misinvest are in part limited by law, and because minority shareholders have enough power to extract it." Of course, La Porta et al also find that in the common law counties, which includes the U.S., low dividend firms are more likely to have very strong investment opportunities. This is also true in my dataset. The mean market-to-book equity ratio for the non-dividend paying firms is about 25 percent higher than for the dividend payers. Since I control for the market-to-book equity ratio in the regressions, however, the dividend payer indicator can be interpreted as acting as a proxy for agency problems.
} 
While some of the ex ante results are consistent with the idea that firms with greater agency problems are more likely to face securities class actions, this does not mean that the class actions necessarily help solve these problems. If they do, we would expect to see changes either in corporate governance mechanisms, or, if the governance mechanisms are working, changes in management. ${ }^{18}$ I turn to this next.

Sample, variable definitions and model specification

This section reports changes in corporate governance structures (ownership structure and board composition) and changes in the probability of managerial displacement (CEO turnover) for a sample of 309 companies that were sued and settled with plaintiffs during the 1991 to 1996 period. Approximately 1,000 class actions were resolved during this period. NERA collected settlements and construct a measure of investor losses typically used by plaintiffs in negotiations for 331 class actions, and I was able to collect information on corporate governance mechanisms for 309 of these.

\footnotetext{
${ }^{18}$ Note that even if there is no change in governance mechanisms, firms may have an incentive to avoid lawsuits if their $\mathrm{D} \& \mathrm{O}$ insurance premiums reflect the risk of facing a class action. For evidence consistent with this hypothesis, see Core (1997).
} 
To test whether governance structures change after class actions, I construct a panel dataset over the 1991 to 1995 period, measuring each of the following governance variables once per year: insider holdings -- the fraction of shares outstanding held by officers and directors; large blockholdings -- the proportion of the firm owned by individuals with at least 5 percent of shares outstanding; institutional holdings -- the proportion of shares outstanding owned by institutions; board size -- the number of individuals on the board of directors ${ }^{19}$ board insiders -the proportion of board members who are also officers of the company; and CEO turnover -- an indicator equal to 1 if the current $\mathrm{CEO}$ is not the same person as the CEO in the previous year.

All of these variables were collected from Compact Disclosure. The insider holdings information comes from the proxy statement. Large blockholdings and institutional holdings are compiled by Spectrum and made available on the Compact Disclosure CD. Board composition and the identity of the CEO are also collected from the proxy statement.

The panel dataset allows me to estimate how each of these governance variables changes

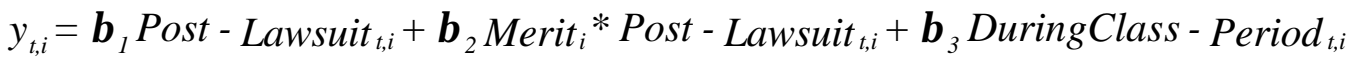

$$
\begin{aligned}
& +\beta_{4} \text { Excess Return }_{t, i}+\beta_{5} \text { Excess Return }_{t-1, i} \\
& + \text { Year }_{t}+\text { Firm }_{i}+\varepsilon_{t, i} \quad i=1, \ldots, 309 ; t=1991, \ldots, 1995
\end{aligned}
$$

after class actions using the following model:

where $y$ is one of the corporate governance variables; Post-Lawsuit is an indicator equal to 1 if the variable is observed after the class-period, which is assumed to be roughly coincident with the filing date of the lawsuit, and 0 otherwise; During Class-Period is an indicator equal to 1 if the

\footnotetext{
${ }^{19}$ Yermack (1996) reports that firms with smaller boards have higher Q ratios.
} 
variable is observed during the class period, and 0 otherwise.

I use a measure of investor losses typically presented by plaintiffs' lawyers in settlement negotiations to construct a measure of the merit of each case. If securities class actions help solve agency problems, then there should be bigger changes in corporate governance after cases with more merit. Merit is a firm-specific but time-invariant variable equal to 1 for cases in which the ratio of the settlement amount to investor losses exceeds the median in the sample ( 9 percent), and zero otherwise. ${ }^{20}$ This specification is also flexible enough to accommodate the possibility that some class actions are nuisances that represent legal rent-seeking; no changes in the governance variables should occur following these cases. ${ }^{21}$

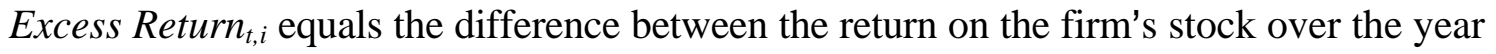
ending at $t$ and the return on the value-weighted portfolio of stocks trading on NYSE, AMEX and NASDAQ. Stock price performance appears in the model because class actions are generally associated with steep price declines. ${ }^{22}$ Therefore, it is important to separate the effects of price performance from the effects of the lawsuit. Stock performance has been shown to be related to institutional holdings (Remolona, Kleiman and Gruenstein, 1997), board composition (Bhagat and Black, 1997) as well as CEO Turnover (see Denis, Denis, and Sarin 1997). Also, I control for turnover in the model with the other corporate governance variables (ownership and board

${ }^{20}$ I have also constructed an alternative merit indicator equal to 1 for cases that have an above-median ratio of settlement to investor losses and that settled for at least $\$ 2$ million. These results are similar to the ones reported in Table 7. For a detailed description of the calculation of investor losses, see Martin et al (1996).

21 The data are not observed at the same time each year, since dates associated with proxy statements vary by company. Consequently, the year indicators reflect the calendar year in which each data point was observed.

${ }^{22}$ The average stock price declined at the end of the class period by about 19 percent before the Reform Act and 31 percent after (Grundfest and Perino, 1997). 
composition). I do this because all of these governance variables may change during periods of managerial turnover.

The model also contains both year and firm fixed effects. These are included to capture time trends and unexplained differences in the levels of the corporate governance variables across firms. The coefficient $\beta_{1}$ can therefore be interpreted as the change in the dependent variable after cases with below average merit, while $\beta_{2}+\beta_{1}$ gives the change in the dependent variable after cases with above average merit. The coefficient $\beta_{3}$ measures any changes that may occur leading up to the lawsuit. For instance, insider trading or issuance of new equity during the class period could affect the level of insider holdings.

In the model with CEO age as the dependent variable, I also include the age of the CEO in the preceding year. The models with insider holdings, large blockholders, institutional holdings, board size and insiders on the board are all estimated with OLS (with fixed effects). The model with CEO turnover as the dependent variable is estimated with a conditional logit model, which is equivalent to including a firm-specific component in the error term.

Results

Table 4 contains the simple summary statistics for the variables before and after the law suits. As it turns out, Table 4 tells the same story as the regressions: there are no statistically significant differences in the governance variables before and after the lawsuits. CEO turnover, however, increases markedly after the lawsuit, from about 11.9 percent before to about 23.2 percent after, an increase of more than 10 percentage points that almost doubles the risk.

Tables 5 and 6 report the regressions for the board composition and ownership structure variables. In neither case do I find statistically significant changes that can plausibly be attributed 
to the effects of the class actions. Board structure does not change significantly after the lawsuits, although there is a statistically significant increase in the size of the board during the class period. The result is not affected by the merit of the case. For the share of insiders on the board, I find no statistically significant changes.

Insider holdings decline after the lawsuit. This decline, however, is not statistically significantly different from the decline in insider holdings observed during the class period. Taken together, these results are consistent with insiders selling stock or issuing new shares during the class period to take advantage of an over valued company, but the lawsuit itself having no effect on insider holdings. In fact, Niehaus and Roth (1998) find that companies that face securities class actions sold more new securities during the class period than a size- and industry-matched control group of firms. They find no evidence of insider selling. Notice that the decline in the proportion of the firm owned by insiders during the class period is mirrored by an increase in the proportion owned by institutions. I find no statistically significant change in large blockholdings, either during or after the class period.

While governance structures do not change, the increase in the unconditional probability of turnover (Table 4) continues to be significant in the conditional logit model (Table 7). ${ }^{23}$ Moreover, the increase in CEO turnover appears to be driven by the high-merit cases. That is, the coefficient on the post-lawsuit indicator is not statistically significantly different from zero, but the coefficient on the interaction between the merit indicator and the post-lawsuit indicator is

\footnotetext{
${ }^{23}$ The number of observations in the conditional logit is less than half of the number of observations in the OLS regressions. This loss of observations occurs because firms that experienced no CEO turnover (either before or after the lawsuit) do not contribute to the coefficient estimates in the conditional logit. For details, see Greene (1997).
} 
significant (Table 7, column 2). ${ }^{24}$

24 If the model is estimated on just the set of cases with high merit, the coefficient on the post-lawsuit indicator is statistically significant (not shown). 
One might object that all that has been shown is that CEO turnover rises following large, single-day stock price declines. To rule out this possibility, I have collected CEO turnover information from the 1991 to 1995 period for a randomly selected group of firms that experienced at least a 15 percent stock price decline in 1992 but did not face a securities class action. ${ }^{25}$ I then add these observations to the panel data set, allowing the inclusion of both an indicator equal to 1 after the large stock price decline (this variable is labeled "Indicator for post class-period" in Table 7, which is somewhat of a misnomer in this specification), and an interaction term between this indicator and another indicator equal to 1 for the set of firms that faced a class action. As shown in column 3, the coefficient on the post-class period indicator is not statistically significant, suggesting that large single-day stock price declines are not associated with increased CEO turnover (controlling for past performance). The interaction term, however, is statistically significant at the 10 percent level, and the sum of the coefficients on the post-class period indicator and the interaction term is statistically significant at the 5 percent level. CEO turnover does increase when a large single-day stock price decline occurs in conjunction with a securities class action.

Why does CEO Turnover go up?

${ }^{25}$ The median stock price decline for the firms that do not face a class action is 33 percent. For the firms that do face a class action, the median decline at the end of the class period is 18 percent. 
Financial distress may be associated with the incidence of securities class actions.

Previous research suggests that the incidence of CEO turnover increases during and shortly after financial distress (Gilson and Vetsuypens, 1993). Perhaps turnover goes up because financial distress is correlated with the presence of a class action. Table 8 rules this interpretation out. Here, the turnover regressions are estimated for companies that were profitable during the years from the end of the class period through $1996 .{ }^{26}$ In the simple specification, the coefficient on the post-lawsuit indicator remains at about 1.4, although its standard error increases due to the smaller sample. ${ }^{27}$ The coefficient on the post-lawsuit indicator is statistically significant at the 10.8 percent level. In the second specification (Table 8 , column 2), the merit interaction term is positive and statistically significant, and the sum of the interaction term and the linear term, which gives the total effect of class actions on the probability of CEO turnover for the meritorious cases, is statistically significant (at the 5 percent level).

A second potential problem with the results in Table 7 is that CEO turnover may be endogenous to the presence of a securities class action. Specifically, lawyers may have an incentive to sue companies that have had declines in their stock price that led to CEO turnover. Perhaps CEO turnover causes lawsuits, rather than the reverse. To check for this possibility, I estimate a model like those in Table 7 with an indicator variable equal to 1 after the lawsuit is filed, and another indicator variable equal to 1 during the window of time between the end of the class-period and the filing date. If turnover causes lawsuits but not the reverse, then we should

${ }^{26}$ Profitable firms are those that had positive net income on average over the period from the end of the class period to 1996.

\footnotetext{
${ }^{27}$ Net income is available for 225 of the 309 companies in the dataset. Slightly more than half of these (113) were profitable after the end of the class period.
} 
observe a significant increase in CEO turnover during the window between the end of the class period and the filing date, but no significant increase in turnover after the filing date.

Just the opposite occurs: there is no significant increase in turnover during the window between the end of the class period and the filing date, although the coefficient is positive (Table 9). In contrast, there is a statistically significant increase in CEO turnover after the lawsuit filing date. ${ }^{28}$ Also, in this specification I can not reject the hypothesis that the probability of CEO turnover increases more following meritorious class actions, although the coefficient on the merit interaction is positive. In this model, the likelihood of CEO turnover increases for both relatively high settlement and low settlement cases.

\section{Conclusions}

Securities class actions represent more than mere legal rent-seeking -- they seem to help solve agency problems. Part of the success of capital markets in the U.S., reflected by the relatively unconcentrated ownership structure here, may be attributed to the ability of lawyers to organize a class action against corporate officers and directors. Lawyers have powerful incentives to collect information and act on that information because they typically receive one-third of settlements, thereby overcoming the free-rider problem for small shareholders.

Two key findings support this conclusion. First, firms that are more likely to suffer from agency problems are more likely to face class actions. Risky firms, large firms, young firms, low market-to-book firms and non-dividend paying firms as of the end of 1990 were more likely to face a class action filing over the January 1991 to March 1998 period. Second, the probability of

\footnotetext{
28 The number of observations falls from 347 to 225 when the filing date is added to the model.
} 
CEO turnover increases dramatically after class action filings, from about 11.9 percent per year before to about 23 percent per year after. The increase in turnover seems to be driven by cases with above-average merit; the evidence that turnover increases following cases with belowaverage merit is less robust. Moreover, the increase can not be explained by omitted firm-specific characteristics, financial distress, or the possibility that CEO turnover increases the likelihood that a lawyer will file a class action.

Finally, I find no evidence that corporate governance mechanisms either predict class action filings, or change after they actually occur. Ownership structure in 1990 is not related to filings in either a linear or non-linear way, and neither ownership structure nor board composition change after the class actions. Taken together, these results are consistent with optimal governance in which these various mechanisms are uncorrelated with residual agency problems in equilibrium. 


\section{References}

Agrawal, Anup, Jeffrey F. Jaffe, and Jonathan M. Karpoff. 1998. "Management Turnover and Corporate Governance Changes Following the Revelation of Fraud," mimeo.

Alexander, Cindy and Mark A. Cohen. 1997. "Why do Corporations become Criminals? Ownership, Hidden Actions and Crime as an Agency Cost," mimeo 1997.

Alexander, Janet Cooper. 1991. "Do the Merits Matter? A Study of Settlements in Securities Class Actions," Stanford Law Review.

Berle, Adolf and Gardiner Means. 1932. The Modern Corporation and Private Property (Macmillan, New York).

Beck, James and Sanjai Bhagat. 1997. "Share Price Drops and Shareholder Litigation," University of Colorado, mimeo.

Bhagat, Sanjai and Bernard Black. 1997. "Do Independent Directors Matter?” mimeo, 1997.

Core, John E. 1997. “The Directors' and Officers' Insurance Premium: An Outside Assessment of the Cost of Weak Corporate Governance, mimeo.

Denis, David J. and Diane K. Denis. 1995. "Performance Changes following Management Dismissals," Journal of Finance 50, 1029-58

Denis, David J., Diane K. Denis and Atulya Sarin. 1997. “Ownership Structure and Top Executive Turnover, Journal of Financial Economics 45, 193-222.

Demsetz, Harold and Kenneth Lehn. 1985. "The Structure of Corporate Ownership: Causes and Consequences," Journal of Political Economy, 93(6), 1155-77.

Dunbar, Frederick C. and Vinita M. Juneja. 1994. "Making Securities Class Actions More Responsive to the Modern Shareholder," in Securities Class Actions: Abuses and Remedies (National Legal Center for the Public Interest).

Fazzari, Steven M., R. Glenn Hubbard and Bruce Petersen. 1988. "Financing Constraints and Corporate Investment," Brooking Papers on Economic Activity, no. 1, 141-95.

Gilson, Stuart C. and Michael R. Vetsuypens. 1993. "CEO Compensation in Financially Distressed Firms: An Empirical Analysis," Journal of Finance 48(2), 425-58.

Gorton, Gary and Matthais Kahl. 1997. "Rich Investors, Institutional Investors and Corporate Governance," mimeo. 
Greene, William. 1993. Econometric Analysis (Macmillian, New York, second edition).

Grundfest, Joseph A. and Michael A. Perino. 1997. "Securities Litigation Reform: The First Year's Experience," working paper, John M. Olin Program in Law and Economics no. 140.

Himmelberg, Charles P. and Donald P. Morgan. 1995. "Is Bank Lending Special?" in Is Bank Lending Important for the Transmission of Monetary Policy, edited buy Joe Peek and Eric Rosengren, Federal Reserve Bank of Boston, Conference Series no. 39.

Holderness, Clifford G., Randall S. Kroszner, and Dennis P. Sheehan. 1997. "Were the Good Old Days That Good? Changes in Managerial Stock Ownership Since the Great Depression," mimeo, November 1997.

Jensen, Michael C. 1986. "Agency Costs of Free Cash Flow, Corporate Finance, and Takeovers," American Economic Review Paper and Proceedings 76, 323-29.

Jensen, Michael C. and Kevin J. Murphy. 1990. "Performance Pay and Top-Management Incentives," Journal of Political Economy 98(2), 225-264.

Jensen, Micheal C. and William Meckling. 1976. "Theory of the Firm: Managerial Behavior, Agency Costs, and Ownership Structure, Journal of Financial Economics 3, 305-60.

Jones, Christopher and Scott Weingram. 1996. "The Determinants of 10b-5 Litigation Risk," working paper, John M. Olin Program in Law and Economics no. 118.

Kaplan, Steven and Luigi Zingales. 1997. "Do Investment-Cash Flow Sensitivities Provide Useful Measures of Financing Constraints?" Quarterly Journal of Economics (February), 169-215.

La Porta, Rafael, Florencio Lopez-de-Silanes, Andrei Shleifer and Robert W. Vishny. 1997. "Legal Determinants of External Finance," Journal of Finance 52(3), 1131-50.

La Porta, Rafael, Florencio Lopez-de-Silanes, Andrei Shleifer and Robert W. Vishny. 1998. "Agency Problems and Dividend Policies around the World," mimeo.

Martin, Denise N., Vinita M. Juneja, Todd S. Foster and Frederick C. Dunbar. 1996. "Recent Trends IV: What Explains Filings and Settlements in Shareholder Class Actions?" National Economic Research Associates.

Morck, Randall, Andrei Shleifer, and Robert Vishny. 1988. "Management Ownership and Market Valuation: An Empirical Analysis," Journal of Financial Economics 20, 293-316. 
Morck, Randall, Andrei Shleifer and Robert W. Vishny. 1989. "Alternative Mechanisms for Corporate Control," American Economic Review 79, 842-52.

Myers, Stewart C. and Raghuram G. Rajan. 1995. "The Paradox of Liquidity," NBER working paper no. 5143.

Niehaus, Greg and Greg Roth. 1998. "Insider Trading, Equity Issues and CEO Turnover in Firms Subject to Securities Class Action," mimeo.

Pagano, Marco and Alisa Röell. 1998. "The Choice of Stock Ownership Structure: Agency Costs, Monitoring, and the Decision to go Public," Quarterly Journal of Economics, 113(1), 187-226.

Prowse, Stephen. 1996. "Corporate Finance in International Perspective: Legal and Regulatory Influences in Financial System Development," Federal Reserve Bank of Dallas Economic Review.

Remolona, Eli, M., Paul Kleiman and Debbie Gruenstein. 1997. "Market Returns and Mutual Fund Flows," Federal Reserve Bank of New York Economic Policy Review 3(2), 33-52.

Romano, Roberta. 1991. "The Shareholder Suit: Litigation without Foundation?" Journal of Law, Economics and Organization 7, 55-87.

Schranz, Mary. 1993. "Takeovers Improve Firm Performance: Evidence from the Banking Industry," Journal of Political Economy 101, 299-326.

Shleifer, Andrei and Robert W. Vishny. 1997. "A Survey of Corporate Governance," Journal of Finance, Vol 52(2), 737-783.

Smith, Clifford W. and Ross L. Watts. 1992. "The Investment Opportunity Set and Corporate Financing, Dividend, and Compensation Policies," Journal of Financial Economics 32, 363-92.

Yermack, David. 1996. "Higher market valuation of companies with a small board of directors," Journal of Financial Economics 40, 185-213. 
Table 1: Predicted relationship between firm characteristics and the likelihood of a securities class action

Predicted effect of variable on class action likelihood under:

Hypothesis 1:

Securities class actions help solve agency problems
Hypothesis 2:

Securities class actions occur because lawyers seek rents

Firm characteristics

Size

Market-to-book ratio

$+$ $+$

Tangible assets

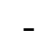

0

Risk

Trading volume

0

0

Age

$-$

0

Regulated firm indicator

$-$

0

Variables potentially used to

solve agency problems

Insider holdings

?

Leverage

$?$

Dividend payout

$?$

0 
Table 2: Mean, standard deviation and median for 1990 balance sheet characteristics of Compustat companies

\begin{tabular}{|c|c|c|}
\hline & $\begin{array}{c}\text { Compustat companies } \\
\text { sued between } \\
1 / 91 \text { and } 3 / 98\end{array}$ & $\begin{array}{l}\text { Other Compustat } \\
\text { companies }\end{array}$ \\
\hline $\begin{array}{l}\text { Market value of equity } \\
\text { (Millions of dollars) }\end{array}$ & $\begin{array}{c}1102 \\
(3691) \\
{[135]}\end{array}$ & $\begin{array}{c}610 \\
(2908) \\
{[25]}\end{array}$ \\
\hline Market-to-book equity ratio & $\begin{array}{c}3.01 \\
(6.58) \\
{[1.48]}\end{array}$ & $\begin{array}{c}4.01 \\
(78.68) \\
{[1.17]}\end{array}$ \\
\hline $\begin{array}{l}\text { Property, plant \& equipment / } \\
\text { total assets }\end{array}$ & $\begin{array}{l}0.28 \\
(0.24) \\
{[0.21]}\end{array}$ & $\begin{array}{c}0.32 \\
(0.27) \\
{[0.25]}\end{array}$ \\
\hline $\begin{array}{l}\text { Standard deviation of monthly } \\
\text { stock return, 1986-90 }\end{array}$ & $\begin{array}{l}0.13 \\
(0.05) \\
{[0.12]}\end{array}$ & $\begin{array}{l}0.12 \\
(0.05) \\
{[0.11]}\end{array}$ \\
\hline $\begin{array}{l}\text { Average monthly trading } \\
\text { volume/shares outstanding }\end{array}$ & $\begin{array}{l}86.78 \\
(68.82) \\
{[67.30]}\end{array}$ & $\begin{array}{c}55.06 \\
(53.20) \\
{[44.01]}\end{array}$ \\
\hline $\begin{array}{l}\text { Number of year stock has been } \\
\text { trading }\end{array}$ & $\begin{array}{c}15.7 \\
(16.1) \\
{[9]}\end{array}$ & $\begin{array}{c}15.5 \\
(14.6) \\
{[10]}\end{array}$ \\
\hline $\begin{array}{l}\text { Proportion of firms in regulated } \\
\text { industries }\end{array}$ & $\begin{array}{c}0.13 \\
- \\
-\end{array}$ & $\begin{array}{c}0.12 \\
- \\
-\end{array}$ \\
\hline Proportion of banking & $\begin{array}{c}0.06 \\
- \\
-\end{array}$ & $\begin{array}{c}0.02 \\
- \\
-\end{array}$ \\
\hline $\begin{array}{l}\text { Proportion of firms in computer } \\
\text { hardware and software }\end{array}$ & $\begin{array}{c}0.12 \\
- \\
-\end{array}$ & $\begin{array}{c}0.06 \\
- \\
-\end{array}$ \\
\hline
\end{tabular}

Table 2: Mean, standard deviation and median for 1990 balance sheet characteristics of Compustat companies (continued) 
Proportion of shares held by officers and directors

(Insider holdings)

Leverage

(Debt/assets)
0.17

(0.19)

[0.11]

0.22

$(0.25)$

[0.15]

0.48
0.24

$(0.22)$

[0.18]

0.23

(0.97)

[0.14]

0.47

dividend between 1986 and 1990

Sources and Notes: All figures except share holdings of insiders are from the 1990 Compustat. Insiders' shareholdings are from Compact Disclosure, based on information from the 1990 proxy statement. The first number reported is the sample mean, the second number (in parentheses) is the standard deviation, and the third number [in square brackets] is the median. Standard deviations and medians are not reported for indicator variables. 
Table 3: Firms with greater agency problems are more likely to face securities class action lawsuits

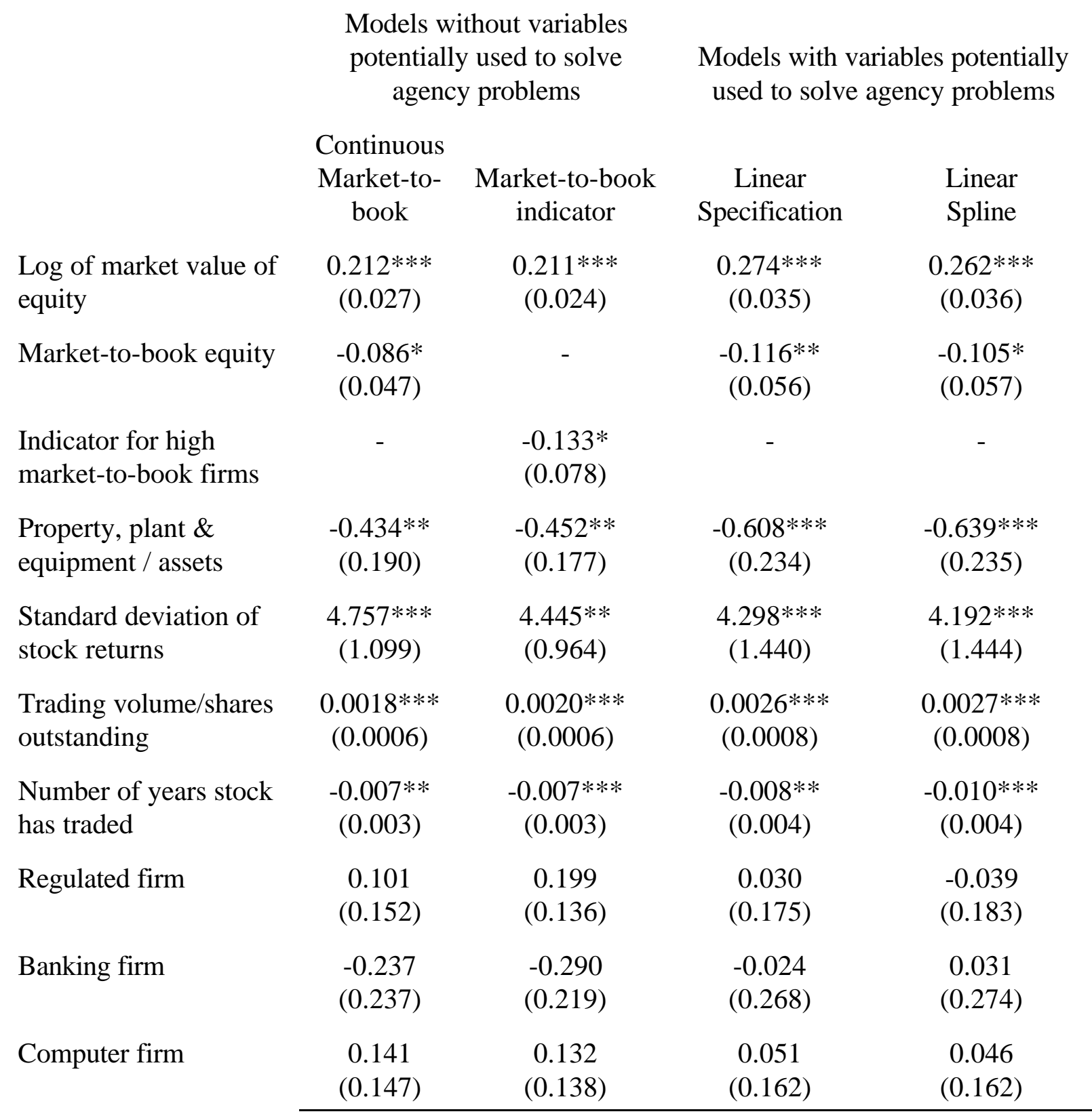

Table 3: Firms with greater agency problems are more likely to face securities class action lawsuits (continued)

Insider holdings

$-0.293$

$-4.360$

$(0.280)$

(3.629)

Insider holdings $>5 \%$,

3.933 
Insider holdings $>25 \%$, 0 otherwise

Leverage

Dividend payor indicator

$\mathrm{N}$

Pseudo- ${ }^{2}$
$-$

-

$-$

$0.575^{*}$

(0.320)

0.412

-

$-$

$-0.383 * * *$

(0.122)

2,282

1,699

0.1107
$0.570 *$

$-0.383 * * *$

(0.122)

1,699

Sources and Notes: Dependent variable equals the number of times a firm faced a securities class action between 1/91 and 3/98; the dependent variable ranges from 0 to 6 . Approximately 10 percent of the companies on Compustat were sued at least once during the period. Model estimated is an ordered probit. All data except insider holdings are from 1990 Compustat. Insiders' shareholdings are from Compact Disclosure, based on information from the 1990 proxy statement. Firms with market-to-book equity above 4.63 (the 90 percentile of the distribution) are dropped in the model with market-to-book entered continuously. Standard errors appear below coefficients in parentheses. ***Statistically significant at the $1 \%$ level; **Statistically significant at the $5 \%$ level; *Statistically significant at the $10 \%$ level. 


\section{Table 4: Mean, standard deviation and median of corporate governance variables before and after securities class actions}

Before lawsuit

Board size

Proportion of board members
who are officers

Proportion of shares held by officers and directors

Proportion of share held by

large blockholders
(4.253)

[7]

0.335

(0.184)

[0.333]

0.191

(0.190)

[0.120]

0.261

(0.259)

[0.183]

0.354

(0.241)

[0.342]
After lawsuit

[7]

0.303

(0.166)

[0.286]

0.130

(0.148)

[0.075]

0.253

(0.251)

[0.197]

0.355

(0.234)

[0.337]

Probability of CEO Turnover

0.119

0.232

Sources and Notes: Data are a panel from Compact Disclosure, with observations between 1991 and 1995 . The first number reported is the sample mean, the second number (in parentheses) is the standard deviation, and the third number [in square brackets] is the median. Firms included are drawn from a sample of cases that settled between 1991 and 1996. 


\section{Table 5: Board composition does not change after securities class actions}

\begin{tabular}{lcccc} 
& \multicolumn{2}{c}{ Board size } & \multicolumn{2}{c}{ who are officers } \\
& $\begin{array}{c}\text { Simple } \\
\text { Specification }\end{array}$ & $\begin{array}{c}\text { Specification } \\
\text { with Merit }\end{array}$ & $\begin{array}{c}\text { Simple } \\
\text { Specification }\end{array}$ & $\begin{array}{c}\text { Specification } \\
\text { with Merit }\end{array}$ \\
Intercept & $8.686^{* * *}$ & $8.688^{* * *}$ & $0.338^{* * *}$ & $0.338^{* * *}$ \\
& $(0.169)$ & $(0.170)$ & $(0.012)$ & $(0.012)$ \\
Indicator for post- & 0.221 & 0.256 & -0.006 & -0.011 \\
lawsuit period & $(0.263)$ & $(0.292)$ & $(0.019)$ & $(0.021)$ \\
Merit*Indicator for & - & -0.080 & - & 0.013 \\
post-lawsuit period & & $(0.288)$ & & $(0.021)$ \\
During class period & $0.495 * *$ & $0.492^{* *}$ & -0.010 & -0.010 \\
indicator & $(0.226)$ & $(0.226)$ & $(0.016)$ & $(0.016)$ \\
CEO turnover & $-0.311 *$ & $-0.308 *$ & 0.012 & 0.011 \\
indicator & $(0.162)$ & $(0.163)$ & $(0.011)$ & $(0.012)$ \\
Stock performance & -0.163 & -0.163 & 0.010 & 0.010 \\
& $(0.108)$ & $(0.108)$ & $(0.008)$ & $(0.008)$ \\
Year indicators: & & & & -0.052 \\
1992 & -0.186 & -0.186 & -0.007 & -0.008 \\
1993 & -0.377 & -0.374 & -0.042 & -0.043 \\
1994 & -0.392 & -0.390 & -0.043 & -0.044 \\
1995 & -0.591 & -0.589 & -0.051 & -0535 \\
$\mathrm{~N}$ & 776 & 776 & 771 & \\
$\mathrm{R}^{2}$ (Within) & 0.0423 & 0.0425 & 0.0528 & \\
\hline
\end{tabular}

Sources and Notes: Model estimated on a panel dataset from Compact Disclosure and CRSP from 1991 to 1995. Stock performance equals the difference between the return on the firm's stock and the return on the market (value-weighted return on NYSE, AMEX and NASDAQ). Standard errors appear below coefficients in parentheses. Year effects are jointly significant at the $1 \%$ level; 1991 is the omitted category. All models contain firm fixed effects. ***Statistically significant at the $1 \%$ level; **Statistically significant at the $5 \%$ level; $*$ Statistically significant at the $10 \%$ level. 
Table 6: Ownership structure changes little following securities class actions

Insider holdings

Simple Specification

$\begin{array}{lcc}\text { Intercept } & \begin{array}{c}0.194 * * * \\ (0.011)\end{array} & \begin{array}{c}0.193 * * * \\ (0.011)\end{array} \\ & -0.050 * * * & -0.048 * * * \\ \text { Indicator for post- } & (0.014) & (0.017) \\ \text { lawsuit period } & - & -0.003 \\ \text { Merit*Indicator for } & & (0.017) \\ \text { post-lawsuit period } & & -0.040 * * * \\ \text { During class period } & -0.040 * * * & (0.013) \\ \text { indicator } & (0.013) & -0.008 \\ \text { CEO turnover } & -0.008 & (0.008) \\ \text { indicator } & (0.008) & 0.003 \\ \text { Stock performance } & 0.003 & (0.005)\end{array}$

Large blockholdings

$\begin{array}{cc}\text { Simple } & \begin{array}{c}\text { Specification } \\ \text { Specification }\end{array} \\ \text { with Merit }\end{array}$

$0.286 * * *$
$(0.020)$
0.039
$(0.028)$
$0.287 * * *$
(0.020)

0.032

(0.025)

0.011

(0.016)

$0.020 *$

(0.010)

0.003

$-0.003$

$-0.012$

$-0.020$

760

0.0796

0.0797

\section{$-0.008$}

$-0.281$

$-0.029$

$-0.008$

805

0.4350
0.028

(0.033)

0.019

(0.032)

Holdings by institutions

$\begin{array}{cc}\begin{array}{c}\text { Simple } \\ \text { Specification }\end{array} & \begin{array}{c}\text { Specification } \\ \text { with Merit }\end{array} \\ 0.362 * * * & 0.362 * * * \\ (0.014) & (0.014) \\ -0.025 & -0.043 * \\ (0.019) & (0.022) \\ - & 0.034 \\ & (0.022) \\ 0.037 * * & 0.037 * \\ (0.017) & (0.017) \\ -0.017 & -0.019 \\ (0.011) & (0.014) \\ 0.038 * * * & 0.038^{* * *} \\ (0.007) & (0.007)\end{array}$

0.032

(0.025)

0.010

(0.016)

$0.020 *$

(0.010)

(0.007)

0.022

0.023

$-0.008$

0.034

0.035

$-0.281$

0.046

0.047

$-0.009$

0.065

0.065

805

805

805

0.1286

0.1324

Sources and Notes: Model estimated on a panel dataset from Compact Disclosure and CRSP from 1991 to 1995. Stock performance equals the difference between the return on the firm's stock and the return on the market (value-weighted return on NYSE, AMEX and NASDAQ). Standard errors appear below coefficients in parentheses. Year effects are jointly significant at the 1\% level; 1991 is the omitted category. All models contain firm fixed effects. 
$* * *$ Statistically significant at the $1 \%$ level; **Statistically significant at the $5 \%$ level; *Statistically significant at the $10 \%$ level. 
Table 7: CEO turnover increases after securities class actions

\begin{tabular}{|c|c|c|c|}
\hline & $\begin{array}{c}\text { Basic } \\
\text { Specification }\end{array}$ & $\begin{array}{l}\text { Specification } \\
\text { with Merit } \\
\text { interaction }\end{array}$ & $\begin{array}{l}\text { Specification that } \\
\text { includes companies } \\
\text { that did not face a } \\
\text { class action }\end{array}$ \\
\hline $\begin{array}{l}\text { Indicator for post class- period } \\
\text { (post large, single-day stock price } \\
\text { decline) }\end{array}$ & $\begin{array}{l}1.431 * * \\
(0.645)\end{array}$ & $\begin{array}{c}0.801 \\
(0.708)\end{array}$ & $\begin{array}{c}0.410 \\
(0.412)\end{array}$ \\
\hline $\begin{array}{l}\text { Firm faced class action indicator } * \\
\text { post class- period indicator }\end{array}$ & - & - & $\begin{array}{l}1.080 * \\
(0.613)\end{array}$ \\
\hline $\begin{array}{l}\text { Merit indicator * post class- } \\
\text { period indicator }\end{array}$ & - & $\begin{array}{l}1.605 * \\
(0.870)\end{array}$ & - \\
\hline During-class-period indicator & $\begin{array}{c}0.264 \\
(0.614)\end{array}$ & $\begin{array}{c}0.328 \\
(0.621)\end{array}$ & $\begin{array}{c}0.271 \\
(0.588)\end{array}$ \\
\hline CEO Age in prior year & $\begin{array}{l}0.151 * * * \\
(0.035)\end{array}$ & $\begin{array}{l}0.146 * * * \\
(0.034)\end{array}$ & $\begin{array}{l}0.102 * * * \\
(0.024)\end{array}$ \\
\hline Stock performance & $\begin{array}{c}-0.573 * * \\
(0.247)\end{array}$ & $\begin{array}{l}-0.569 * * \\
(0.246)\end{array}$ & $\begin{array}{l}-0.340 * \\
(0.181)\end{array}$ \\
\hline Lagged stock performance & $\begin{array}{l}-0.289 \\
(0.256)\end{array}$ & $\begin{array}{l}-0.265 \\
(0.256)\end{array}$ & $\begin{array}{l}-0.224 \\
(0.191)\end{array}$ \\
\hline $\begin{array}{l}\text { Year indicators: } \\
1992\end{array}$ & -0.042 & -0.026 & -0.024 \\
\hline 1993 & 0.104 & 0.078 & 0.140 \\
\hline 1994 & 0.324 & 0.301 & 0.207 \\
\hline 1995 & 0.190 & 0.192 & 0.001 \\
\hline $\mathrm{N}$ & 347 & 347 & 573 \\
\hline Pseudo $\mathrm{R}^{2}$ & 0.1940 & 0.2085 & 0.1127 \\
\hline \multicolumn{4}{|c|}{$\begin{array}{l}\text { Sources and Notes: Model estimated on a panel dataset from Compact Disclosure and CRSP from } 1991 \text { to } 1995 \text {. } \\
\text { Standard errors appear below coefficients in parentheses. The dependent variable equals } 1 \text { if the current CEO is not the } \\
\text { same person has the CEO in the previous year. Stock performance equals the difference between the return on the firm's } \\
\text { stock and the return on the market (value-weighted return on NYSE, AMEX and NASDAQ). The model estimated is a } \\
\text { conditional logit, where the coefficients estimated are conditioned on a firm-specific error component (analogous to a } \\
\text { fixed effect in an OLS model). The merit indicator equals } 1 \text { for suits whenever the ratio of the settlement amount to } \\
\text { investor losses exceeds the median in the sample. } \\
* * * \text { Statistically significant at the } 1 \% \text { level; **Statistically significant at the } 5 \% \text { level; *Statistically significant at the } \\
10 \% \text { level. }\end{array}$} \\
\hline
\end{tabular}




\section{Table 8: CEO turnover increases after securities class actions, even for profitable firms}

\section{Basic Specification}

Indicator for post class-

period

Merit indicator * post class-

period indicator

During-class-period

indicator

CEO Age in prior year

Stock performance

Lagged stock performance

Year indicators:

1992

1993

1994

1995
1.417

(0.883)

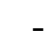

Specification with Merit interaction

0.694

(0.969)

$2.189 *$

0.218

0.277

(0.928)

(0.970)

$0.215 * * *$

(0.052)

$0.205^{* * *}$

(0.051)

$-0.112$

$-0.150$

(0.363)

(0.364)

0.162

0.146

(0.388)

(0.387)

$\begin{array}{lll}\text { Pseudo } \mathrm{R}^{2} & 0.2242 & 0.2478\end{array}$

Sources and Notes: Model estimated on a panel dataset from Compact Disclosure and CRSP from 1991 to 1995 , including only firms that had positive net income over the period beginning at the end of the class period and ending in 1996. Standard errors appear below coefficients in parentheses. The dependent variable equals 1 if the current CEO is not the same person has the CEO in the previous year. Stock performance equals the difference between the return on the firm's stock and the return on the market (value-weighted return on NYSE, AMEX and NASDAQ). The model estimated is a conditional logit, where the coefficients estimated are conditioned on a firm-specific error component (analogous to a fixed effect in an OLS model). The merit indicator equals 1 for suits whenever the ratio of the settlement amount to investor losses exceeds the median in the sample.

***Statistically significant at the $1 \%$ level; **Statistically significant at the $5 \%$ level; *Statistically significant at the $10 \%$ level. 


\section{Table 9: CEO turnover increases after filing date but not before}

\begin{tabular}{|c|c|c|}
\hline & Basic Specification & $\begin{array}{r}\text { Specification witl } \\
\text { interaction }\end{array}$ \\
\hline $\begin{array}{l}\text { Indicator for post filing-date } \\
\text { period }\end{array}$ & $\begin{array}{l}2.163 * * * \\
(0.794)\end{array}$ & $\begin{array}{l}1.805^{* *} \\
(0.841)\end{array}$ \\
\hline $\begin{array}{l}\text { Merit indicator * post filing- } \\
\text { date indicator }\end{array}$ & - & $\begin{array}{c}0.908 \\
(0.877)\end{array}$ \\
\hline $\begin{array}{l}\text { Post class-period but before } \\
\text { filing-date indicator }\end{array}$ & $\begin{array}{c}1.171 \\
(0.908)\end{array}$ & $\begin{array}{c}1.020 \\
(0.924)\end{array}$ \\
\hline $\begin{array}{l}\text { During-class-period } \\
\text { indicator }\end{array}$ & $\begin{array}{c}0.452 \\
(0.642)\end{array}$ & $\begin{array}{c}0.314 \\
(0.621)\end{array}$ \\
\hline CEO Age in prior year & $\begin{array}{l}0.127 * * * \\
(0.042)\end{array}$ & $\begin{array}{c}0.123 * * * \\
(0.042)\end{array}$ \\
\hline Stock performance & $\begin{array}{l}-0.509 \\
(0.334)\end{array}$ & $\begin{array}{l}-0.492 \\
(0.336)\end{array}$ \\
\hline Lagged stock performance & $\begin{array}{c}0.073 \\
(0.323)\end{array}$ & $\begin{array}{c}0.090 \\
(0.325)\end{array}$ \\
\hline $\begin{array}{l}\text { Year indicators: } \\
1992\end{array}$ & -0.321 & -0.315 \\
\hline 1993 & -0.727 & -0.755 \\
\hline 1994 & -0.252 & -0.274 \\
\hline 1995 & -0.666 & -0.693 \\
\hline $\mathrm{N}$ & 225 & 225 \\
\hline Pseudo $\mathrm{R}^{2}$ & 0.2081 & 0.2150 \\
\hline
\end{tabular}

Sources and Notes: Model estimated on a panel dataset from Compact Disclosure and CRSP from 1991 to 1995.

Standard errors appear below coefficients in parentheses. The dependent variable equals 1 if the current CEO is not the same person has the CEO in the previous year. Stock performance equals the difference between the return on the firm's stock and the return on the market (value-weighted return on NYSE, AMEX and NASDAQ). The model estimated is a conditional logit, where the coefficient estimated are conditioned on a firm-specific error component (analogous to a fixed effect in an OLS model). The merit indicator equals 1 for suits whenever the ratio of the settlement amount to investor losses exceeds the median in the sample.

***Statistically significant at the $1 \%$ level; **Statistically significant at the $5 \%$ level; *Statistically significant at the $10 \%$ level. 
